\title{
Biogeochemical silica mass balances in Lake Michigan and Lake Superior
}

\section{CLAIRE L. SCHELSKE}

Great Lakes Research Division and Department of Atmospheric and Oceanic Science, The University of Michigan, Ann Arbor, MI 48109, USA

Key words: Biogenic silica, geochemical, sedimentation, diatom production, diatom dissolution, Great Lakes

\begin{abstract}
Silica budgets for Lake Michigan and Lake Superior differ in several respects. Mass balance calculations for both lakes agree with previous studies in that permanent burial of biogenic silica in sediments may be only about $5 \%$ of the biogenic silica produced by diatoms. Because dissolution rates are large, good estimates of permanent burial of diatoms can not be obtained indirectly from the internal cycle of silica (silica uptake by diatoms and subsequent dissolution) but must be obtained from the sediment stratigraphy. The annual net production of biogenic silica in Lake Michigan requires $71 \%$ of the winter maximum silica reservoir which must be maintained primarily by internal cycling in this large lake whereas the comparable silica demand in Lake Superior is only $8.3 \%$. The greater silica demand in Lake Michigan is the result of phosphorus enrichment which has increased diatom production. It is hypothesized that steady-state silica dynamics in Lake Michigan were disrupted by increased diatom production between 1955 and 1970 and that a new steady state based on silica-limited diatom production developed after 1970. Mass balance calculations for Lake Michigan show in contrast with previous work that the hypothesized water column silica depletion of $3.0 \mathrm{~g} \cdot \mathrm{m}^{-3}$ could have occurred even though $90 \%$ or more of the biogenic silica production is recycled.
\end{abstract}

\section{Introduction}

Oceanographers have been concerned for a number of years with the silica cycle and the problems of obtaining a silica mass balance for the oceans (see Calvert 1983, DeMaster 1981). In contrast relatively little work has been done on silica mass balances in the Great Lakes. The only comprehensive study was the mass balance for Lake Superior by Johnson and Eisenreich (1979). Questions related to mass balances were addressed for Lake Michigan (Parker et al., 1977), for Lake Erie and Lake Ontario (Nriagu, 1978), and for Lake Huron (Robbins, 1980).

Certain characteristics of the Great Lakes are ideal for studies of silica mass balances. Lake Michigan and Lake Superior are large with hydraulic residence times of 100 and 1.38 years (Schelske and Roth 1973) and silica residence times of 36 and 69 years, respectively (Table 1). Therefore, these systems are similar to the oceans in that the quantity of silica in the water 
Table 1. Comparison of silica dynamics in the Great Lakes and oceans

\begin{tabular}{|c|c|c|c|c|}
\hline & $\begin{array}{l}\text { Lake } \\
\text { Michigan a }^{2}\end{array}$ & $\begin{array}{l}\text { Lake } \\
\text { Ontariob }\end{array}$ & $\begin{array}{l}\text { Lake } \\
\text { Superior }\end{array}$ & Oceans $^{d}$ \\
\hline $\begin{array}{l}\text { Water mass dissolved } \\
\mathrm{SiO}_{2}\left(10^{12} \mathrm{~g}\right)\end{array}$ & 7.2 & 0.75 & 29 & $5.5 \times 10^{6}$ \\
\hline $\begin{array}{l}\text { River inputs } \\
\left(10^{12} \mathrm{~g} \cdot \mathrm{yr}^{-1}\right)\end{array}$ & 0.20 & 0.12 & 0.42 & $600^{f}$ \\
\hline $\begin{array}{l}\text { Residence } \\
\text { time (yrs) }\end{array}$ & 36 & 6.2 & 69 & 13000 \\
\hline $\begin{array}{l}\text { Biological uptake } \\
\left(10^{12} \mathrm{~g} \cdot \mathrm{yr}^{-1}\right)\end{array}$ & $5.2-6.4^{e}$ & 0.59 & $2.4-6.8^{e}$ & $1.0-3.2 \times 10^{4}$ \\
\hline $\begin{array}{l}\text { Biological residence } \\
\text { time (yrs) }\end{array}$ & $1.1-1.4^{\mathrm{e}}$ & 1.3 & $4.3-12^{\mathrm{e}}$ & $170-690$ \\
\hline
\end{tabular}

${ }^{a}$ From Parker et al. (1977) ${ }^{b}$ From Nriagu (1978) ${ }^{c}$ From Johnson and Eisenreich (1979)

${ }^{d}$ From Calvert (1983) ${ }^{e}$ Lower estimate of biological uptake and higher estimate of biological residence time are from this study ${ }^{1}$ Includes inputs of $270 \times 10^{12} \mathrm{~g} \cdot \mathrm{yr}^{-1}$ from hydrothermal influx and sea floor weathering

mass is not affected greatly by annual inflows or outflows. Because of much shallower depths, they differ from the oceans in that a larger fraction of the silica reservoir in the water mass is utilized annually in biogenic silica production. This relationship is evident from the 100 -fold shorter residence times of biogenic silica in Lake Michigan and Lake Ontario compared to the oceans. These deep lakes also are holomictic so homogeneous silica concentrations occur annually during the winter-spring thermal mixing period. Annual net diatom production therefore can be estimated indirectly from silica disappearance in the water column without correcting for inputs from upwelling, sediments, or tributaries except in the relatively small nearshore zone (Schelske et al., 1984). These conditions contrast markedly with those in shallow fresh-water systems (Bailey-Watts, 1976), estuarine systems (D'Elia et al., 1983), and nearshore Lake Michigan (Quigley and Robbins, 1984) where sediment release is important on time scales that are much shorter than one year and from large, shallow Canadian lakes which have maximum diatom production in late summer and autumn (Hecky et al. in prep.).

Silica mass balances differ from those in the oceans because it appears that steady-state conditions have not been maintained in any of the Great Lakes during the past 150 years. From studies of biogenic silica in sediments, (Schelske et al., 1983b) inferred that silica depletion occurred not only in Lake Michigan waters in the 1960s but also in Lake Erie and Lake Ontario in the 1800s. Robbins (1980) speculated that silica dynamics in Lake Huron were not steady state because outputs exceeded inputs and because rates of amorphous silica deposition increased $50 \%$ in recent sediments. Recently obtained data also indicate that rates of biogenic silica accumulation have increased in recent Lake Superior sediments (Stoermer et al. in prep). 
Silica dynamics in Lake Superior and Lake Michigan differ in several respects. Comparing silica mass balances for these lakes is of particular interest because Lake Superior is the most oligotrophic and has the smallest silica demand whereas the silica demand in Lake Michigan is the greatest among the Great Lakes (Schelske, 1975). In addition, epilimnetic silica concentrations in Lake Michigan are reduced during summer stratification to limiting concentrations for diatom growth, whereas in Lake Superior minimum concentrations are greater than the maximum concentrations in Lake Michigan (Table 2). The greatest contrast then, as hypothesized by Schelske and Stoermer (1971), is that the reservoir of silica in Lake Michigan was depleted by the late 1960 s to the extent that silica concentrations became limiting for epilimnetic diatom production. This recent change in the biogeochemical mass balance of silica in Lake Michigan has been attributed to the production response of diatoms to increased phosphorus loadings (Schelske and Stoermer, 1972). Silica depletion and its effect on phytoplankton assemblages are major consequences of eutrophication in the Great Lakes (Stoermer, 1978) and possibly in marine systems (Officer and Ryther, 1980).

Table 2. Comparison of dissolved silica concentrations in the Great Lakes. Summer epilimnetic minimum and winter maximum concentrations are representative of the early 1970s. All data are in $\mathrm{g} \mathrm{SiO}_{2} \cdot \mathrm{m}^{-3}$

\begin{tabular}{lcl}
\hline Lake & Summer min. & Winter max. \\
\hline Ontario $^{\mathrm{a}}$ & 0.1 & 0.4 \\
Erie, eastern basin $^{\mathrm{a}}$ & $<0.1$ & 0.3 \\
Erie, central basin $^{\mathrm{a}}$ & $<0.1$ & 0.4 \\
Michigan $^{\mathrm{b}}$ & 0.1 & 1.5 \\
Huron $^{\mathrm{a}}$ & 1.1 & 1.9 \\
Superior $^{\mathrm{a}}$ & 2.3 & 2.4 \\
\hline
\end{tabular}

${ }^{2}$ Data from Dobson et al. (1974) and Weiler (1981)

${ }^{b}$ Data from Rousar (1973) and Schelske et al. (1980)

The Schelske-Stoermer silica depletion hypothesis has been questioned because of the apparent lack of increased permanent sedimentation of diatoms (Parker and Edgington, 1976) commensurate with the postulated decreases in silica concentrations and from a reanalysis of the Chicago water filtration plant data (Shapiro and Swain, 1983). However, there is now evidence that increases in permanent sedimentation of biogenic silica did indeed occur in Lake Michigan (Schelske and Conley, in prep.).

This paper will be used to show that apparently contradictory conclusions about silica dynamics in the Great Lakes can be resolved if one distinguishes between geochemical mass balances and internal cycles of silica. The internal cycle, as used by Calvert (1983), is controlled in large lakes mainly by silica uptake for diatom production (Table 1) and subsequent dissolution of 
diatoms either in the water column or sediments. Thus, it has been concluded correctly that permanent sedimentation of diatoms is a small fraction of diatom production (see Parker et al., 1977). It will be shown in this paper, however, that changes in biogeochemistry can not be addressed adequately with rates from the internal cycle. Rather, the most critical needs in geochemical mass balances are for data on permanent sedimentation of diatoms or biogenic silica and on inputs and outflow losses of silica.

This paper will also compare silica mass balances for Lake Michigan and Lake Superior. This comparison will show that diatom production is the major factor controlling annual silica dynamics in Lake Michigan. In contrast, it will be shown that it is critical to verify the assumption of steady state in constructing a mass balance for Lake Superior because of a smaller silica demand for diatom production. This comparison also shows that biogeochemical silica mass balances can be changed rapidly even though permanent sedimentation of diatoms is a small fraction of diatom production.

\section{Approach}

The data presented in this paper will be given without error limits because I wish to point out the need for additional information and to stimulate interest in addressing questions related to silica mass balances. In addition, it will be obvious that because of expected uncertainties in the data, attempting to set error limits would contribute little at this point to questions which have been raised about silica mass balances.

Mass balances can be calculated with Eqn. 1 in which in puts equal losses.

$$
\mathrm{AI}+\mathrm{TI}+\mathrm{SR}=\mathrm{SD}+\mathrm{OL}+\Delta \mathrm{M}
$$

where $\mathbf{A I}=$ annual atmospheric inputs; $\mathbf{T I}=$ annual tributary inputs; $\mathrm{SR}=$ annual sediment release; $\mathrm{SD}=$ annual sediment deposition; $\mathrm{OL}=$ annual outflow loss; and $\Delta \mathrm{M}=$ annual change in mass at winter maximum.

This mass balance equation contains two terms, sediment release and sediment deposition, which are part of the internal silica cycle as-used by Calvert (1983), but does not include permanent sedimentation. Thus sediment deposition as defined in Eqn. (2) must be distinguished from permanent sedimentation as defined in Eqn. (3).

$$
\begin{aligned}
& \mathrm{SD}=\mathrm{DP}-\mathrm{DD} \\
& \mathrm{PS}=\mathrm{SD}-\mathrm{SR}
\end{aligned}
$$

where $\mathrm{DP}=$ annual diatom production; $\mathrm{DD}=$ annual diatom dissolution in water column and nepheloid layer; and PS = annual permanent sedimentation.

Sediment deposition is the fraction of net diatom production that is not recycled in the water column and nepheloid layer whereas sedimented biogenic silica that is recycled is included as sediment release in Eqns. (1) and 
(3). Because of resuspension of sedimented diatoms, the distinction between diatom dissolution in the nepheloid layer and surficial sediments may be largely operational.

If Eqns. (1) and (3) are combined in order to eliminate the internal cycle terms, permanent sedimentation equals the difference between the sum of the input terms and outflow losses for steady-state conditions (Eqn. 4).

$$
\mathrm{PS}=\mathrm{TI}+\mathrm{AI}-\mathrm{OL}-\Delta \mathrm{M}
$$

Data will be presented in mass units as $\mathrm{SiO}_{2}$ both as mass loadings to the lake and in terms of areal loads. Areal loads are used to facilitate comparison of in-lake rate processes, particularly those for production and sedimentation of diatoms. Silica or dissolved silica is used for the soluble form in water and biogenic silica is used for amorphous silica found in diatoms and other siliceous algae.

\section{Diatom production}

Net diatom production can be estimated indirectly from the disappearance of dissolved and biogenic silica from the water column as described by Schelske et al. (1984). Annual net diatom production in $\mathrm{g} \cdot \mathrm{m}^{-2} \cdot \mathrm{yr}^{-1}$ can be calculated from average daily rates of net diatom production for different periods of the annual production cycle as shown in Eqn. 5.

$$
D P=\frac{Z_{m}\left(C_{w m}-C_{s c}\right)}{t_{2}-t_{1}}+\frac{Z_{t}\left(C_{s c}-C_{s m}\right)}{t_{3}-t_{2}}+U D
$$

where

$Z_{\mathfrak{m}}=$ average water depth in $\mathrm{m}$

$Z_{t}=$ trophogenic zone depth in $m$

$\mathrm{C}_{\mathrm{wm}}=$ winter maximum concentration in $\mathrm{g} \cdot \mathrm{m}^{-3}$

$\mathrm{C}_{\mathrm{sc}}=$ minimum spring circulation concentration in $\mathrm{g} \cdot \mathrm{m}^{-3}$

$\mathrm{C}_{\mathrm{sm}}=$ minimum summer trophogenic zone concentration in $\mathrm{g} \cdot \mathrm{m}^{-3}$

$\mathrm{UD}=$ Unmeasured loss after period of summer minimum in $\mathrm{g} \cdot \mathrm{m}^{-2} \cdot \mathrm{d}^{-1}$ and $t_{1}, t_{2}$, and $t_{3}$ are Julian dates which define periods for $C_{w m}$, $\mathrm{C}_{\mathbf{s c}}$, and $\mathrm{C}_{\mathrm{sm}}$.

Silica lost from the water column is termed net production because production dependent on recycled or new silica is not accounted for with this disappearance method.

\section{Sediment release}

Quigley and Robbins (1984) summarized silica release rates which have been measured either directly in enclosures containing undisturbed sediments and overlying water or predicted from profiles of interstitial silica concentrations. Mean release rates generally ranged from $26-58 \mathrm{~g} \cdot \mathrm{m}^{-2} \cdot \mathrm{yr}^{-1}$ for most experiments with the exception of larger measured fluxes in Lake Erie and 
Saginaw Bay and smaller predicted fluxes for Lake Ontario and Lake Superior. Smaller predicted fluxes reported by Quigley and Robbins (1984) for nearshore sandy sediments in Lake Michigan may be the result of the high energy nearshore environment which does not allow the accumulation of sediment and burial of diatoms. Thus their low predicted fluxes and high measured silica tluxes indicate rapid dissolution of biogenic silica in surticial nearshore sediments.

Other differences among sediment release rates can be related to expected differences in rates of net diatom production that can be inferred from data on the annual silica cycle (Table 2) and from data on primary production and standing crops of phytoplankton (Vollenweider et al., 1974). Low release rates from Lake Ontario and Lake Superior sediments would be expected from the relatively small annual changes in silica concentrations in the water mass. The largest measured release rates, exceeding $100 \mathrm{~g} \cdot \mathrm{m}^{-2} \cdot \mathrm{yr}^{-1}$, were from sediments in the highly productive western basin of Lake Erie and Saginaw Bay.

\section{Lake Michigan internal cycle}

\section{Net diatom production}

Schelske et al. (1984) estimated net production of biogenic silica in Lake Michigan from the beginning of the annual diatom production cycle to the end of the summer stratification period (see Eqn. 5). The calculated value based on a mean depth of $84 \mathrm{~m}$ was $70 \mathrm{~g} \cdot \mathrm{m}^{-2} \cdot \mathrm{yr}^{-1}$ with the assumptions that $\mathrm{C}_{\mathrm{wm}}$ was $1.4 \mathrm{~g} \cdot \mathrm{m}^{-3}, \mathrm{C}_{\mathrm{sc}}$ was $1.0 \mathrm{~g} \cdot \mathrm{m}^{-3}$, and $\mathrm{C}_{\mathrm{sm}}$ was $0.10 \mathrm{~g} \cdot \mathrm{m}^{-3}$ over a $40 \mathrm{~m}$ trophogenic zone.

The autumn phytoplankton bloom which would contribute most to UD (Eqn. 5) does not occur until late September or early October. The autumn standing crop of chlorophyll $a$ is much smaller than in the spring bloom (Rousar 1973; Ladewski and Stoermer, 1973) as is the standing crop of biogenic silica (Schelske et al., 1983a; Glover, 1982). During autumn, epilimnetic diatom production depends on entrainment of silica from metalimnetic waters, which also may have reduced silica concentrations (Schelske et al., 1983a). Smaller phytoplankton production compared to the spring would also be expected in the autumn based on reduced inputs of solar radiation. Expected irradiance at $42-45^{\circ} \mathrm{N}$ on clear days during the spring bloom in May or June is two or three times greater than during the autumn bloom in October or November (Hutchinson, 1957).

Sediment trap data also indicate that autumn production is not large. Biogenic silica fluxes measured from 15 September-15 November with sediment traps at offshore stations totaled $7.5 \mathrm{~g} \cdot \mathrm{m}^{-2}$ for the 2-month period (Schelske et al., 1984). If this flux represents net diatom production and is doubled to compensate for production that may have been missed by late 
placement of traps and then added to the calculated flux for the earlier part of the year a total annual flux of $85 \mathrm{~g} \cdot \mathrm{m}^{-2} \cdot \mathrm{yr}^{-1}$ is obtained.

High near-shore diatom production probably contributes relatively little to the lake-wide average because the nearshore zone, defined as the area $<40 \mathrm{~m}$ deep, represents only $20 \%$ of the lake's surface area (Schelske et al., 1983a). If diatom production is two to three times greater in the nearshore than in the offshore as suggested by sediment trap fluxes (Schelske et al., 1984) and primary production data (Fee, 1973), then average net production for the entire lake would be increased only $20-40 \%$. Higher diatom production in the nearshore than predicted with Eqn. (5) probably results from combined inputs of silica from tributaries, upwelling, and rapid recycling; only new silica supplied from tributaries and upwelling should be included in calculations of annual net production of biogenic silica (Schelske et al., 1984).

It is not likely that nearshore diatom production several fold greater than offshore rates could be maintained over the entire nearshore zone because nearshore enrichment from tributaries is restricted mainly to the southern part of the lake (Schelske et al., 1980). If the offshore average of 85 $\mathrm{g} \cdot \mathrm{m}^{-2} \cdot \mathrm{yr}^{-1}$ were increased $20-40 \%$ to account for greater nearshore production, the average lake-wide production would be 102-119 $\mathrm{g} \cdot \mathrm{m}^{-2} \cdot \mathrm{yr}^{-1}$. The annual tributary loading of $20.5 \times 10^{10} \mathrm{~g} \cdot \mathrm{yr}^{-1}$ is equivalent to a net diatom production of only $3.5 \mathrm{~g} \cdot \mathrm{m}^{-2} \cdot \mathrm{yr}^{-1}$ averaged over the entire lake. This smaller estimate of increased nearshore net diatom production from tributary inputs will be used to obtain a lake-wide average of $89 \mathrm{~g} \mathrm{SiO}_{2} \cdot \mathrm{m}^{-2} \cdot \mathrm{yr}^{-1}$.

\section{Sediment deposition}

Sediment deposition can be estimated from data on diatom production and an assumption about the fraction of production that is dissolved in the water column (Eqn. 2). In contrast with previous reports that biogenic silica is recycled primarily in the water column (Conway et al., 1977), sediment trap (Schelske et al., 1984) and water column data (Schelske et al., 1983a) from deep stations indicate that a significant fraction of the diatom production is sedimented.

\section{Sediment release}

Given the limited amount of data, it is not possible to directly estimate an average release rate for Lake Michigan. Release rates measured previously in Grand Traverse Bay (see Glover, 1982) and Lake Michigan (Quigley and Robbins, 1984) were used to obtain high and low estimates for lake-wide rates by assuming that the three depositional zones have different release rates. Cahill (1981) found that depositional basins represented $40 \%$, transitional areas $15 \%$, and non-depositional areas $45 \%$ of the lake bottom. A maximum representative value was obtained by assuming that depositional 
basins have a release rate of $49 \mathrm{~g} \cdot \mathrm{m}^{-2} \cdot \mathrm{yr}^{-1}$, transitional areas have a release rate of $14 \mathrm{~g} \cdot \mathrm{m}^{-2} \cdot \mathrm{yr}^{-1}$, and non-depositional areas have a negligible release rate. The resulting basin-weighted average is $22 \mathrm{~g} \cdot \mathrm{m}^{-2} \cdot \mathrm{yr}^{-1}, 90 \%$ of which is attributable to release from depositional basins. If the low range of release rates $\left(31 \mathrm{~g} \cdot \mathrm{m}^{-2} \cdot \mathrm{yr}^{-1}\right)$ is used for depositional basins, the resulting basinweighted average is $15 \mathrm{~g} \cdot \mathrm{m}^{-2} \cdot \mathrm{yr}^{-1}$. The assumption that release rates are negligible in non-depositional areas is at variance with data reported by Quigley and Robbins (1984) who found an average release rate equivalent to $57 \mathrm{~g} \cdot \mathrm{m}^{-2} \cdot \mathrm{yr}^{-1}$ for nearshore sediments off the Grand River. These high rates of internal cycling show that nearshore diatom production can be enhanced greatly by recycled silica which would not contribute to net diatom production.

\section{Lake Michigan losses}

\section{Outflow}

Estimating outflow losses is complicated by several factors. The rate of outflow through the Straits of Mackinac cannot be measured conventionally because Lake Michigan and Lake Huron have the same hydraulic level. As a consequence, flow between the two lakes is oscillatory (Saylor and Sloss, 1976). Summer subsurface flow from Lake Huron with relatively high levels of dissolved silica is entrained with the outflow from Lake Michigan, increasing the apparent outflow concentrations. This enrichment only affects the apparent concentration of silica and should not influence the calculation of outflow loss of silica which depends on the net loss of water from Lake Michigan and the silica concentrations in adjacent Lake Michigan surface waters. Outflowing waters may contain less silica on the average than Lake Michigan waters because silica depletion is greater in the shallow waters to the west and south of the Straits of Mackinac than in the deeper offshore waters (Schelske et al., 1983a).

To estimate outflow loss, an outflow of $4.8 \times 10^{10} \mathrm{~m}^{3} \cdot \mathrm{yr}^{-1}$ (Schelske and Roth, 1973) was assumed to have maximum silica concentrations of $1.4 \mathrm{~g} \cdot \mathrm{m}^{-3}$ for two months and minimum concentrations of $0.20 \mathrm{~g} \cdot \mathrm{m}^{-3}$ for two months of the year. These changes in concentration were set to correspond with seasonal changes in epilimnetic silica concentrations (Rousar, 1973). During the remaining eight months, the concentration was either increased from the minimum to the maximum or decreased from the maximum to the minimum yielding an average concentration of $0.80 \mathrm{~g}^{\cdot \mathrm{m}^{-3}}$. The annual outflow loss is then $38 \times 10^{9} \mathrm{~g} \mathrm{yr}^{-1}$. The minimum was set at $0.20 \mathrm{~g} \cdot \mathrm{m}^{-3}$ so a contribution of at least $0.10 \mathrm{~g} \cdot \mathrm{m}^{-3}$ of biogenic silica is included in the average. Epilimnetic concentrations of biogenic silica may range as large as $0.30 \mathrm{~g} \cdot \mathrm{m}^{-3}$ during the spring and early summer but decrease to $0.10 \mathrm{~g} \cdot \mathrm{m}^{-3}$ or less in the late fall (Schelske et al., 1983a). If the biogenic 
silica contribution is underestimated by $0.10 \mathrm{~g} \cdot \mathrm{m}^{-3}$ averaged over the year, the outflow loss would increase by $13 \%$ to $43 \times 10^{9} \mathrm{~g} \cdot \mathrm{yr}^{-1}$. An outflow loss of $71 \times 10^{9} \mathrm{~g} \cdot \mathrm{yr}^{-1}$ (International Joint Commission, 1976) was rejected because it is equivalent to an average outflow concentration of $1.5 \mathrm{~g} \cdot \mathrm{m}^{-3}$, essentially equal to the winter maximum concentration (Table 2).

\section{Lake Michigan inputs}

\section{Atmospheric inputs}

Atmospheric inputs of silica are much smaller than inputs from tributaries or sediments. An annual input of $7.99 \times 10^{9} \mathrm{~g} \cdot \mathrm{yr}^{-1}$ was estimated by Eisenreich et al. (1977) for Lake Michigan. Annual inputs of $9.20 \times 10^{9}$. $\mathrm{g} \cdot \mathrm{yr}^{-1}$ for Lake Huron and $26.1 \times 10^{9} \mathrm{~g} \cdot \mathrm{yr}^{-1}$ for Lake Superior were reported by the International Joint Commission (1976). Average areal loading rates calculated from these data for Lake Michigan $\left(0.137 \mathrm{~g} \cdot \mathrm{m}^{-2} \cdot \mathrm{yr}^{-1}\right)$ are lower than for Lake Huron and Lake Superior $(0.154$ and 0.316 . $\mathrm{g} \cdot \mathrm{m}^{-2} \cdot \mathrm{yr}^{-1}$, respectively). An immediate explanation for the larger areal loading to Lake Superior is not apparent because only data on total loads are given in the report by IJC.

\section{Tributary inputs}

There have been two studies of tributary inputs. Ayers (1970) used data collected by the U.S. Public Health Service in 1963-64 to obtain corrected loadings of $2.01 \times 10^{11} \mathrm{~g} \cdot \mathrm{yr}^{-1}$ and Upchurch (1972) reported loadings of $2.10 \times 10^{11} \mathrm{~g} \cdot \mathrm{yr}^{-1}$. Parker et al. (1977) averaged these two estimates which is also used here and is equivalent to an average concentration of $4.3 \mathrm{~g} \cdot \mathrm{m}^{-3}$.

\section{Lake Michigan mass balances}

\section{Steady state 1970-present}

It is assumed from historical data on open-water silica concentrations that mass-balances in Lake Michigan have approximated steady state since 1970. Steady-state silica dynamics are indicated by summer minimum and winter maximum concentrations that appear to have been maintained at $0.1-0.2$ $\mathrm{g} \cdot \mathrm{m}^{-3}$ and ca. $1.4 \mathrm{~g} \cdot \mathrm{m}^{-3}$, respectively, since 1970 (Figure 1 ).

Sediment deposition and sediment release are the two terms in the mass balance equation (Eqn. 1) that have not been estimated previously. One approach to obtain estimates was to calculate sediment deposition indirectly with Eqn. (2) from net diatom production over a range of values for diatom dissolution (Table 3) and then to balance the input-output terms in Eqn. (1) with values for sediment release obtained by difference. The other approach was to assume that estimates for sediment release were representative and then calculate sediment deposition by difference with Eqn. (1). From the 


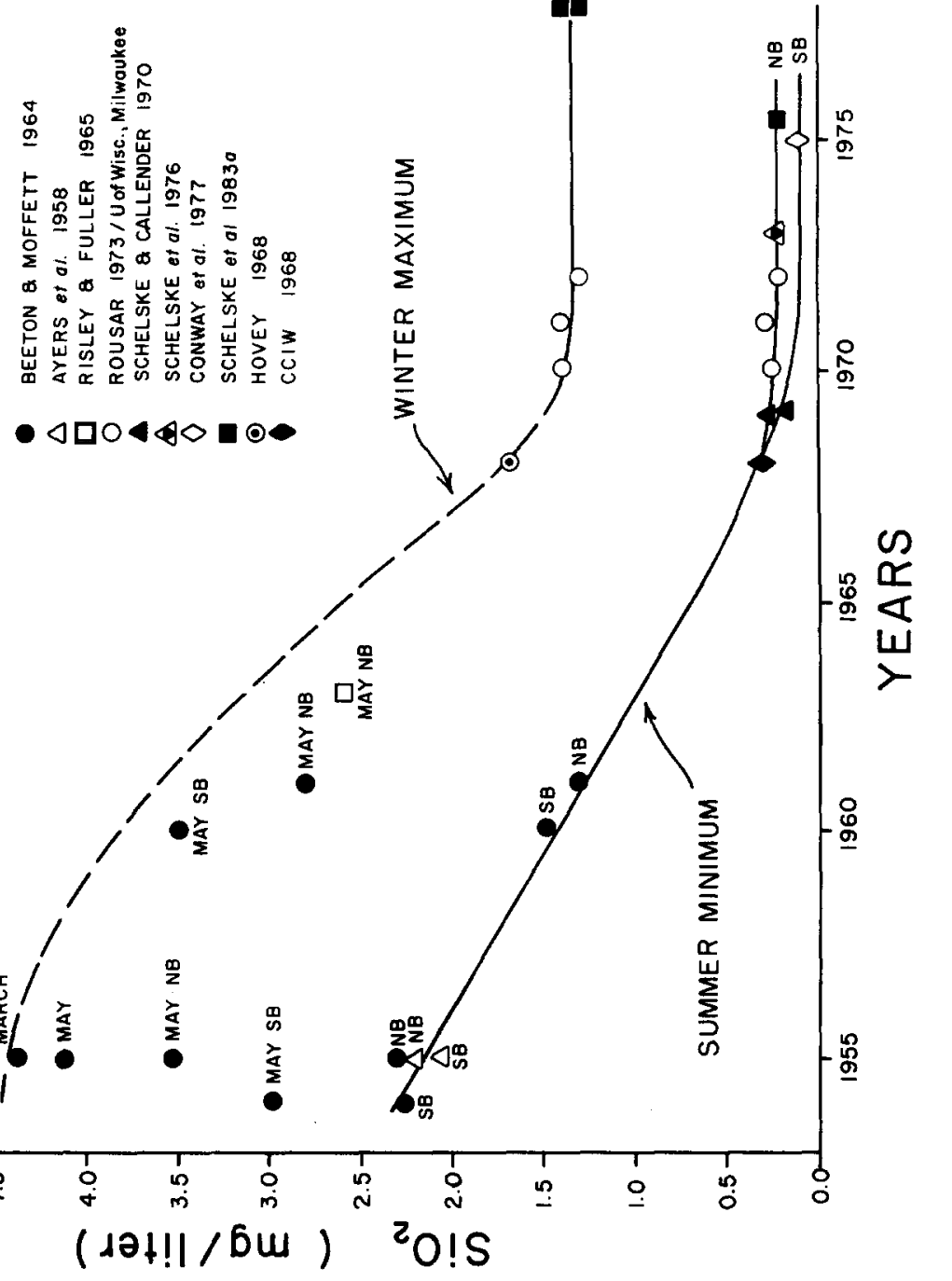

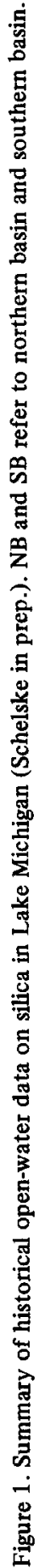


Table 3. Effects of varying dissolution rates on sediment deposition or permanent sedimentation (see Eqns. 2 and 3) of diatoms. All values are $\mathrm{g} \mathrm{SiO}_{2} \cdot \mathrm{m}^{-2} \cdot \mathrm{yr}^{-1}$

\begin{tabular}{lccc}
\hline & \multicolumn{3}{c}{ Dissolution (\%) } \\
\cline { 2 - 4 } & 80 & 90 & 95 \\
\hline Diatom production $^{\mathrm{a}}$ & 110 & 110 & 110 \\
Sediment deposition $^{-}$ & 22 & 11 & 5.5 \\
Diatom productionb $_{\text {Sediment deposition }}$ & 89 & 89 & 89 \\
\hline
\end{tabular}

a Parker et al. (1977) ${ }^{\mathbf{b}}$ This study

high and low estimates for sediment release, sediment deposition rates ranging from $18-25 \mathrm{~g} \cdot \mathrm{m}^{-2} \cdot \mathrm{yr}^{-1}$ were obtained (Table 4).

Several important points are evident from these calculations. First, diatom production is obviously dependent on recycled silica, ie. diatom dissolution and release of soluble silica from the sediments. Second, the indirect calculation of sediment deposition is affected greatly by small changes in the assumed fraction of diatom production that is dissolved in the water column. Increasing the rate of dissolution from $80-90 \%$ decreases the rate of sediment deposition by a factor of two, from $22-11 \mathrm{~g} \cdot \mathrm{m}^{-2} \cdot \mathrm{yr}^{-1}$ (Table 3 ). Third, sediment release or sediment deposition under these assumptions also vary greatly because both were varied to obtain a steady-state mass balance for inputs and losses.

Table 4. Silica mass balance (steady-state) for silica limitation period after 1970 in Lake Michigan based on high and low estimates of silica release. Sediment losses (sediment deposition) are calculated by difference. All values are $\mathrm{g} \mathrm{SiO}_{2} \cdot \mathrm{m}^{-2} \cdot \mathrm{yr}^{-1}$

\begin{tabular}{lcc}
\hline & \multicolumn{2}{c}{ Sediment release } \\
\cline { 2 - 3 } & High & Low \\
\hline Losses: Outflow & 0.74 & 0.74 \\
Sediment deposition & 25 & 18 \\
Total & 26 & 19 \\
Inputs: Tributary & 3.6 & 3.6 \\
Atmosphere & 0.1 & 0.1 \\
Sediment release & 22 & 15 \\
Total & 26 & 19 \\
\hline
\end{tabular}

Silica depletion 1955-1970

A mass balance for the silica-depletion period can be calculated if it is assumed that concentrations decreased $3.0 \mathrm{~g} \cdot \mathrm{m}^{-3}$ over a $15 \cdot$ year period from 1955-1970 (Figure 1). The total loss of silica from the water mass for this $15-\mathrm{yr}$ period is then $14 \times 10^{12} \mathrm{~g}$. Thus, permanent sedimentation and outflow during the silica-depletion period exceeded inputs by $0.93 \times$ $10^{12} \mathrm{~g} \cdot \mathrm{yr}^{-1}$ or $16 \mathrm{~g} \cdot \mathrm{m}^{-2} \cdot \mathrm{yr}^{-1}$ averaged over the lake surface. 
Outflow losses for the silica-depletion period were calculated with the following assumptions: the maximum outflow concentration decreased from $4.4 \mathrm{~g} \cdot \mathrm{m}^{-3}$ in 1955 to $1.4 \mathrm{~g} \cdot \mathrm{m}^{-3}$ in 1970 and the seasonal change in outflow concentration ranged from $2.0-4.4 \mathrm{~g} \cdot \mathrm{m}^{-3}$ in 1955 (Figure 1). Seasonal data for 1955 were averaged with the same approach that was used for the steadystate period to obtain an average concentration of $3.2 \mathrm{~g} \cdot \mathrm{m}^{-3}$ and an annual outflow loss of $15 \times 10^{10} \mathrm{~g} \cdot \mathrm{yr}^{-1}$. This represents a $2.4 \mathrm{~g} \cdot \mathrm{m}^{-3}$ greater outflow loss than the average during the post-1970 steady-state period. If an assumed contribution for greater standing crops of diatoms (biogenic silica) in 1955 amounting to $0.4 \mathrm{~g} \cdot \mathrm{m}^{-3}$ is added, the total for increased outflow loss in 1955 compared to 1970 is $2.8 \mathrm{~g} \cdot \mathrm{m}^{-3}$. The average outflow loss is then 1.4 $\mathrm{g} \cdot \mathrm{m}^{-3} \cdot \mathrm{yr}^{-1}$ greater during the 15 -year period than during the post-1970 steady-state period if the decrease in concentration is assumed to be linear. This annual loss term of $6.7 \times 10^{10} \mathrm{~g} \cdot \mathrm{yr}^{-1}$ obviously can not be a large fraction of the total loss of $14 \times 10^{12} \mathrm{~g}$ for the 15 -year period of rapid silica depletion.

Table 5. Comparison of geochemical silica mass balances for steady state and rapid silica depletion periods in Lake Michigan. Losses during the silica depletion period are $16 \mathrm{~g} \cdot \mathrm{m}^{-2} \cdot \mathrm{yr}^{-1}$ greater than inputs to account for a hypothesized $3.0 \mathrm{~g} \cdot \mathrm{m}^{-3}$ decrease in water column silica. All values are $\mathrm{g} \mathrm{SiO}_{2} \cdot \mathrm{m}^{-2} \cdot \mathrm{yr}^{-1}$

\begin{tabular}{|c|c|c|}
\hline & $\begin{array}{l}\text { Steady state } \\
1970-\end{array}$ & $\begin{array}{l}\text { Silica depletion } \\
1955-1970\end{array}$ \\
\hline $\begin{aligned} \text { Inputs: } & \text { Tributary } \\
& \text { Atmosphere }\end{aligned}$ & $\begin{array}{l}3.6 \\
0.14\end{array}$ & $\begin{array}{l}3.6 \\
0.14\end{array}$ \\
\hline $\begin{array}{l}\text { Losses: Outflow } \\
\text { Permanent sedimentation }\end{array}$ & $\begin{array}{l}0.74 \\
3.0\end{array}$ & $\begin{array}{r}1.9 \\
17.8\end{array}$ \\
\hline
\end{tabular}

Permanent sedimentation was calculated for the steady-state and silica depletion periods using Eqn. (4), assuming that $\Delta \mathrm{M}$ decreased 16 $\mathrm{g} \cdot \mathrm{m}^{-2} \cdot \mathrm{yr}^{-1}$ during the silica depletion period to reflect a $3.0 \mathrm{~g} \cdot \mathrm{m}^{-3}$ decrease in silica concentrations in the water mass. These calculations indicate that permanent sedimentation was 6 -fold greater during the silica depletion period than during the steady-state period (Table 5). This relative increase appears to be quite large; however, it should be pointed out that calculated permanent sedimentation is very sensitive to changes in inputs or losses. It is not likely that errors in estimating atmospheric inputs are large enough to significantly affect calculated permanent sedimentation. However, overestimates of outflow losses or underestimates of tributary inputs could be significant. A $10 \%$ change in tributary inputs would change calculated permanent sedimentation $12 \%$ but a $10 \%$ change in atmospheric inputs would change calculated permanent sedimentation $<0.5 \%$.

\section{Lake Superior mass balance}

Net diatom production was estimated with Eqn. (5). An estimate of 37 . $\mathrm{g} \cdot \mathrm{m}^{-2} \cdot \mathrm{yr}^{-1}$ was based on assumptions that silica concentrations decreased 
$0.22 \mathrm{~g} \cdot \mathrm{m}^{-3}$ over the 148-m average depth during the period of thermal mixing and $0.10 \mathrm{~g} \cdot \mathrm{m}^{-3}$ in a 40 -meter trophogenic zone after the lake stratified. This estimate probably exceeds the maximum value that could be expected because open-water silica concentrations, representative of the major fraction of the water mass, only vary about $0.2 \mathrm{~g} \cdot \mathrm{m}^{-3}$ annually (Weiler 1981; International Joint Commission 1977; Dobson et al., 1974). Therefore, a smaller estimate of $21 \mathrm{~g} \cdot \mathrm{m}^{-2} \cdot \mathrm{yr}^{-1}$, based on a $0.10 \mathrm{~g} \cdot \mathrm{m}^{-3}$ change during the thermally mixed period and $0.15 \mathrm{~g} \cdot \mathrm{m}^{-3}$ decrease in the trophogenic zone during thermal stratification, is probably more realistic. The period of strong thermal stratification in Lake Superior extends into September, so the relatively small amount of the annual diatom production after September would be insignificant compared to the difference between the two estimates.

Table 6. Silica mass balances for Lake Superior. Data from Johnson and Eisenreich (1979). Areal loadings were calculated from lake loadings using individual estimates or averages of ranges

\begin{tabular}{lll}
\hline & \multicolumn{2}{c}{ Johnson and Eisenreich } \\
\cline { 2 - 3 } & $\begin{array}{l}\text { Lake loading } \\
10^{10} \mathrm{~g} / \mathrm{yr}\end{array}$ & $\begin{array}{l}\text { Areal loading } \\
\mathrm{g} \cdot \mathrm{m}^{-2} \cdot \mathrm{yr}\end{array}$ \\
\hline Inputs: Tributary & 42 & 5.1 \\
Atmosphere & 2.6 & 0.32 \\
Shoreline erosion & 0.7 & 0.08 \\
Bottom sediments & $2.1-7.8^{\mathrm{a}}$ & $0.59^{\mathrm{a}}$ \\
Total & $47-53$ & $6.1^{\mathrm{b}}$ \\
Losses: & & \\
Outflow & $13-15$ & 1.7 \\
Dissolved silica & $1-2$ & 0.18 \\
Suspended diatoms & & \\
Bottom sediments & $2-3$ & 0.30 \\
Diatoms & 1.0 & 0.1 \\
Particulate adsorption & $19-34$ & 3.2 \\
Silicate authigenesis & $36-55$ & $5.5^{\mathrm{b}}$ \\
Total & &
\end{tabular}

${ }^{a}$ Value should be ten-fold greater (see text) ${ }^{b}$ Inputs and outputs are not equal because some data were presented originally as ranges

Johnson and Eisenreich (1979) compiled a silica mass balance for Lake Superior (Table 6) in which the major loss term is silicate authigenesis. It is perhaps important to re-examine this mass balance because, although Johnson and Eisenreich found what may be authigenic smectite in some cores, they admitted that their evidence for silicate authigenesis was not strong. Only two aspects of their mass balance will be considered. First, are estimates of diatom production and related permanent sedimentation reasonable? Second, is it possible that the lake is not at steady state?

Johnson and Eisenreich (1979) underestimated silica release from the sediments because of a computational error. A 'mean flux of $600 \mu \mathrm{giO}_{2}$ / $\mathrm{cm}^{2} \mathrm{yr}^{\prime}$ is reported in their paper which is consistent with other data for 
sediment release in the Great Lakes (Quigley and Robbins, 1984) and Lake Superior (Glass and Poldoski, 1975). However, in their mass balance this input term ranges from 0.21 to $0.78 \times 10^{8} \mathrm{~kg} \mathrm{SiO}_{2} \cdot \mathrm{yr}^{-1}$; but based on their mean flux from sediments it should have been an order of magnitude greater. This error only affects calculations related to the internal silica cycle and not estimates of permanent sedimentation (see Eqns. 3 and 4).

Table 7. Comparison of silica mass balances and internal recycle in Lake Michigan and Lake Superior. Data are in $\mathrm{g} \mathrm{SiO}_{2} \cdot \mathrm{m}^{-2} \cdot \mathrm{yr}^{-1}$

\begin{tabular}{|c|c|c|c|c|}
\hline & \multicolumn{2}{|c|}{ Lake Michigan } & \multicolumn{2}{|c|}{ Lake Superior } \\
\hline & This study & Parker et al. & $\begin{array}{l}\text { Johnson and } \\
\text { Eisenreich }\end{array}$ & This study \\
\hline $\begin{array}{l}\text { INPUTS } \\
\text { Tributary } \\
\text { Atmospheric } \\
\text { Shoreline erosion }\end{array}$ & $\begin{array}{l}3.6 \\
0.14\end{array}$ & $\begin{array}{l}3.6 \\
0.14\end{array}$ & $\begin{array}{l}5.1 \\
0.32 \\
0.08\end{array}$ & $\begin{array}{l}5.1 \\
0.32 \\
0.08\end{array}$ \\
\hline $\begin{array}{l}\text { LOSSES } \\
\text { Outflow } \\
\text { Permanent sedimentation }\end{array}$ & $\begin{array}{l}0.74 \\
3.0\end{array}$ & $\begin{array}{l}0.74 \\
3.0\end{array}$ & $\begin{array}{l}1.9 \\
3.6\end{array}$ & $\begin{array}{l}1.9 \\
3.6\end{array}$ \\
\hline $\begin{array}{l}\text { INTERNAL RECYCLE } \\
\text { Diatom production } \\
\text { Per cent permanent } \\
\text { sedimentation }\end{array}$ & $\begin{array}{c}89 \\
3.3\end{array}$ & $\begin{array}{l}110 \\
2.7\end{array}$ & $\begin{array}{l}34-103 \\
11-3.5\end{array}$ & $\begin{array}{l}21-37 \\
17-9.7\end{array}$ \\
\hline
\end{tabular}

Calculated permanent sedimentation (Eqn. 4) is $3.6 \mathrm{~g} \cdot \mathrm{m}^{-2} \cdot \mathrm{yr}^{-1}$ for Lake Superior compared to $3.0 \mathrm{~g} \cdot \mathrm{m}^{-2} \cdot \mathrm{yr}^{-1}$ for Lake Michigan (Table 7). Although the accuracy of either estimate could be questioned, it is not likely that permanent sedimentation in Lake Superior is greater than in Lake Michigan. In fact, based on primary productivity (Vollenweider et al., 1974), phosphorus concentrations (Dobson et al., 1974), or diatom production (Table 7), one would expect that permanent sedimentation in Lake Superior would be less than half that in Lake Michigan.

Overestimates of tributary inputs also could explain higher than expected permanent sedimentation. Data for the tributary input term were based essentially on one year of tributary sampling (International Joint Commission, 1977 ) and the resulting estimate is $50 \%$ larger than that given by Nriagu (1978). The average concentration of $8.0 \mathrm{~g} \cdot \mathrm{m}^{-3}$ for tributary inputs is at least three times greater than the lake concentration. The estimated net input of silica (tributary inputs - outflow losses) amounts to $0.31 \times 10^{12} \mathrm{~g} \cdot \mathrm{yr}^{-1}$ which if retained in the water column in the soluble form instead of being attributed to permanent sedimentation in a steady-state model would represent an increase in concentration of only $0.025 \mathrm{~g} \cdot \mathrm{m}^{-3} \cdot \mathrm{yr}^{-1}$.

The validity of the steady-state assumption could be challenged owing to questions about the accuracy of silica data collected prior to 1973. Estimates of average silica concentrations were increased 'from $2.25 \mathrm{mg} / \mathrm{L}$ in $1968-1971$ 
to ca. $2.4 \mathrm{mg} / \mathrm{L}$ in $1973^{\prime}$ to compensate for presumed errors in silica standards that resulted from storage of standards and samples in glass bottles (International Joint Commission, 1977, pp. 311-315). One reason for questioning this adjusted increase of $0.15 \mathrm{~g} \cdot \mathrm{m}^{-3}$ in the $1968-1971$ data is that other data also show that open-water silica concentrations were about $2.2 \mathrm{~g} \cdot \mathrm{m}^{-3}$ in 1970 (Schelske and Roth, 1973). In addition, I have data that indicate maximum concentrations increased about $0.2 \mathrm{~g} \cdot \mathrm{m}^{-3}$ to $2.6 \mathrm{~g} \cdot \mathrm{m}^{-3}$ since 1974 (unpublished data). Weiler (1978) also concluded that silica "possibly increased slightly, since about 1958."

How important is the calculated permanent sedimentation of 3.6 $\mathrm{g} \cdot \mathrm{m}^{-2} \cdot \mathrm{yr}^{-1}$ in relation to the assumption of steady-state conditions in Lake Superior? It represents a $0.025 \mathrm{~g} \cdot \mathrm{m}^{-3} \cdot \mathrm{yr}^{-1}$ silica demand or an annual demand of only $1.0 \%$ of the silica reservoir in the water mass. If permanent sedimentation were $1.5 \mathrm{~g} \cdot \mathrm{m}^{-2} \cdot \mathrm{yr}^{-1}$ (half that of Lake Michigan) instead of $3.6 \mathrm{~g} \cdot \mathrm{m}^{-2} \cdot \mathrm{yr}^{-1}$, the equivalent silica demand would be only 0.014 $\mathrm{g} \cdot \mathrm{m}^{-3} \cdot \mathrm{yr}^{-1}$. These calculations show the necessity for accurate long-term data on water mass concentrations in order to verify the steady-state assumption (see Weiler, 1978).

Inputs of silica associated with disposal of taconite tailings also could be invoked as an unmeasured source of silica inputs. Disposal of tailings from Reserve Mining at Silver Bay, Minnesota, amounted to $24 \times 10^{12} \mathrm{~g}^{\cdot \mathrm{yr}^{-1}}$ for a number of years. If $0.5 \%$ of this load dissolved or was soluble silica it would provide an additional input equivalent to $1.5 \mathrm{~g} \cdot \mathrm{m}^{-2} \cdot \mathrm{yr}^{-1}$ of permanent sedimentation. Interstitial pore water data in cores from Lake Superior indicate that silica release from sediments in the taconite tailings area are much greater than in other areas of the lake (Nriagu, 1978). Therefore, it seems possible that taconite tailings have or are contributing significant amounts of silica which have not been considered in silica mass balances.

There are no clear-cut answers to the two questions posed about mass balances in Lake Superior. Johnson and Eisenreich (1979) probably overestimated sediment deposition of diatoms because they worked with a high estimate of diatom production. Their estimate of diatom production averaged three times greater than the average of my range of estimates and the range of their estimates barely included my larger value (Table 7). If the silica concentration in the lake is actually increasing, as suggested from data presented above, then the absence of assumed steady-state conditions also reduces the rate of permanent sedimentation and the requirement for silicate authigenesis.

\section{Discussion}

The analysis of silica mass balances presented in this paper lead to two important conclusions related to questions about whether silica concentrations have decreased in Lake Michigan. The first is that when the internal recycle 
terms are cancelled out of the steady-state mass balance equation (Eqn. 4), it can be seen that silica depletion in the water column must result if diatom production increases and some fraction of the increased production is not recycled. For silica depletion not to result from increased diatom production, the usual steady-state assumptions for silica mass balances must be altered so that there is either an increase in tributary or atmospheric inputs or an increase in the fraction of biogenic silica that is recycled or both. The other conclusion is that it is incorrect to assume that the sediments are not an important sink for biogenic silica because recycling rates are large. Because recycling rates are $>80 \%$ (Conway et al., 1977), the magnitudes of recycling and diatom production are similar and as a consequence the error in calculating permanent sedimentation based on the small difference between these two parameters that have uncertainties would be unacceptable. Even if an absolute value could be assigned to diatom production, useful estimates of permanent sedimentation can not be obtained unless recycling rates are known with very small errors of precision.

It is obvious from seasonal dynamics or from the short biological residence time of silica that diatom production in Lake Michigan is dependent mainly on recycled silica. However, it may not be as obvious that it is unlikely that good estimates of permanent sedimentation in the Great Lakes can be calculated from estimates of diatom production and dissolution. For example, if dissolution rates ranging from $80-99 \%$ are used to predict sediment deposition and then permanent sedimentation (Eqns. 2 and 3), the result is a range of values that vary 20 -fold. This illustrates that rates of dissolution (recycling) must be known with greater accuracy than can reasonably be expected to obtain useful estimates of permanent sedimentation.

Previously, diatom production was estimated from rates of primary production, assumptions about the fractions of diatoms in the phytoplankton community, and an average silica content of $34 \%$ (Parker et al., 1977) or a silica:carbon weight ratio of 2.3:1.0 (Johnson and Eisenreich, 1979) in diatoms. None of these variables is known with great certainty, especially the average silica:carbon ratio or silica content. Nearly a 6-fold range in silica:carbon weight ratios $(1.3: 1.0-7.6: 1.0)$ and a 2 -fold range in cellular silica content (39-79\%) were reported for 12 species of Great Lakes diatoms (Sicko-Goad et al., 1984). An average silica content or silica:carbon ratio, without good data on species composition, therefore, may be of limited value in estimating silica demand for diatom production.

My method of estimating net diatom production from silica disappearance in the trophogenic zone would appear to be better suited for mass balance calculations than methods used previously in the Great Lakes. Parker et al. (1977) stated that their estimate of the silica required for diatom production might be 'overestimated by a factor of two or three times'. Their estimate of gross diatom production for Lake Michigan was $110 \mathrm{~g} \cdot \mathrm{m}^{-2} \cdot \mathrm{yr}^{-1}$, only $20 \%$ larger than my estimate of net diatom production (Table 7). Agreement 
between the two independent estimates is excellent, especially if it is recog. nized that net production should be less than the production estimated by Parker et al. (1977). Johnson and Eisenreich (1979) started with a three-fold range of values for primary production in Lake Superior and admitted that their value for silica uptake was crude. Their average for primary production was $50 \%$ greater than the average value given by Vollenweider et al. (1974). Their minimum estimate of silica uptake is essentially equal to my maximum estimate of net biogenic silica production (Table 7). Although no error limits can be given, my estimates of net diatom production should be better than a factor of two.

Comparing estimates of net diatom production calculated in this paper from silica disappearance shows that silica demand is much greater in Lake Michigan than in Lake Superior. The estimate of silica demand for net diatom production in Lake Michigan was $89 \mathrm{~g} \cdot \mathrm{m}^{-2} \cdot \mathrm{yr}^{-1}$ during the post.1970 steady-state period. This represents a depletion of $1.0 \mathrm{~g} \cdot \mathrm{m}^{-3} \cdot \mathrm{yr}^{-1}$ averaged over the mean depth of the lake, or $71 \%$ of the winter maximum silica concentration. In contrast, the average silica demand for net diatom production in Lake Superior was $29 \mathrm{~g} \cdot \mathrm{m}^{-2} \cdot \mathrm{yr}^{-1}$, or a depletion rate of only $0.20 \mathrm{~g} \cdot \mathrm{m}^{-3} \cdot \mathrm{yr}^{-1}$ averaged over the mean depth. This represents $8.3 \%$ of the winter maximum concentration, nearly an order of magnitude less than calculated for Lake Michigan. In addition, the silica demand in Lake Michigan would have been greater during the period of rapid silica depletion when diatom growth was not silica limited.

It was concluded from previous studies of diatoms in sedments that it was doubtful that silica depletion could occur in the Great Lakes. Parker and Edgington (1976) reported that diatoms dissolved during sediment burial and therefore that sediments were not a permanent sink for diatoms. Johnson and Eisenreich (1979) reported that a 250 -fold increase in phosphorus loading would be required to cause silica depletion in Lake Superior at the rate postulated for Lake Michigan. Areal estimates of diatom production and permanent sedimentation in Table 7, however, can be used to ask whether these conclusions should be reconsidered. Parker et al. (1977) concluded that permanent sedimentation of diatoms in Lake Michigan was less than 5\% of diatom production. If the rate of diatom production estimated by Parker et al. (1977) for the post-1970 period were doubled to account for greater diatom production during the silica depletion period, the resulting fraction of diatom production required to account for the calculated increase in permanent sedimentation to $18 \mathrm{~g} \cdot \mathrm{m}^{-2} \cdot \mathrm{yr}^{-1}$ is only $8.2 \%$.

Because it was concluded that sediments in the Great Lakes are not significant sinks for diatoms it has been proposed that diagenetic processes affect the chemical form of silica stored in sediments. Several different forms have been advanced: amorphous ferroaluminasilicates were proposed by Nriagu (1978) and authigenic smectite, quartz, or ferroaluminasilicates were suggested by Johnson and Eisenreich (1979). If diagenesis of biogenic silica 
in sediments produces a mineral form, diatom counts may not reflect absolute quantities of silica storage but the mineral phases that are produced must be included as part of the sinks in mass balance calculations.

In this paper calculations of permanent sedimentation have been based on lake-wide averages. This approach is acceptable for mass balances, but it should be recognized that sediment focusing affects the lake-wide pattern of permanent sedimentation of biogenic silica. The effect can be inferred from data on depositional environments. According to Cahill (1981) only $40 \%$ of Lake Michigan is covered by depositional basins with $45 \%$ of the bottom being characterized as non-depositional. Likewise, $54 \%$ of Lake Superior is covered by depositional basins (Thomas and Dell, 1978). Therefore, most of the permanent sedimentation can be expected to be focused over about half the bottom in either lake.

For relatively simple hydraulic systems like the Great Lakes, it should be possible to estimate permanent sedimentation from atmospheric inputs, tributary inputs, and outflow losses provided the assumption of steady state is verified or the change in water mass concentration is included in the calculation. Unfortunately, data for input terms, especially tributary inputs, required to utilize this approach are not well known over time spans of several or more years. Calculated permanent sedimentation of biogenic silica in Lake Michigan from previously published data as summarized in this paper is $3.0 \mathrm{~g} \cdot \mathrm{m}^{-2} \cdot \mathrm{yr}^{-1}$ for the post-1970 steady-state period, less than the $3.6 \mathrm{~g} \cdot \mathrm{m}^{-2} \cdot \mathrm{yr}^{-1}$ calculated for Lake Superior (Table 7). It should be pointed out that these estimates of permanent sedimentation will be affected significantly if tributary inputs or outflow losses have not been estimated accurately or if the steady-state assumption is not valid (Eqn. 4). In addition, inputs from disposal of taconite tailings and release of silica from taconite sediments could represent a significant source of silica which has not been considered in previous mass balances for Lake Superior. If a steady-state assumption is invoked, an unrecognized source of silica input would be required to explain the increased permanent sedimentation of biogenic silica and diatoms (Stoermer et al. in prep.) that have been found recently in cores from Lake Superior.

Comparing mass balance data for Lake Michigan and Lake Superior shows that the assumption of present steady-state conditions in Lake Michigan is a reasonably good approximation for mass balance variables that include the internal cycle of silica. In Lake Michigan, the silica demand for diatom production is nearly equal to the silica reservoir in the water mass. This is not the case in Lake Superior where diatom production is a smaller component of silica dynamics and where the assumption of steady-state conditions becomes much more critical in estimating different terms in the internal cycle. Whether either Lake Superior or Lake Michigan is presently at steady state cannot be verified with certainty from the limited existing data. The limited historical data indicate that since 1970 silica concentrations have been 
stable in Lake Michigan but may have increased as much as $0.4 \mathrm{~g} \cdot \mathrm{m}^{-3}$ in Lake Superior. If steady state has been achieved in Lake Michigan since 1970 , it is obviously a result of the dominating effect of the short biological residence time on silica dynamics. It should be pointed out that the conditions postulated for the period of rapid silica depletion represent a major biogeochemical change in Lake Michigan in which the winter maximum silica concentration decreased $3.0 \mathrm{~g} \cdot \mathrm{m}^{-3}$, from $4.4-1.4 \mathrm{~g} \cdot \mathrm{m}^{-3}$ in only 15 years.

Compiling data presented here on silica mass balances in the Great Lakes leads to two related conclusions. One is that the requirement for permanent sedimentation invoked in previous studies to question silica depletion apparently has been overestimated relative to the quantity that would be necessary to change biogeochemical silica mass balances. The other is increased permanent sedimentation of diatoms resulting from increased diatom production and thus the need to consider non-steady state conditions can not be ignored in geochemical mass balances for the Great Lakes. The critical need for further refinement of silica mass balances therefore is better data on lakewide estimates of permanent sedimentation which can be obtained in these systems with a reasonable amount of sampling effort. Biogenic silica concentrations of samples from dated sediment cores taken in depositional basins and transitional areas are needed to determine the magnitude of permanent sedimentation and whether rates have changed historically (Schelske et al., 1983b). These data and improved estimates of inputs from tributaries and other sources appear to be the essential requirements for more accurate mass balances.

\section{Acknowledgments}

I am grateful to E.F. Stoermer for many fruitful discussions on silica problems and to T.C. Johnson for many helpful comments on early drafts of the manuscript. I also am grateful to D.J. Conley for compiling data on silica fluxes from sediments and reviewing the manuscript and to T.L. Newberry and C.D. Campbell for reading the manuscript. This research was partially supported by a grant from the National Science Foundation (OCE-8216588) and represents Contribution 425, Great Lakes Research Division.

\section{References}

Ayers, J.C. 1970. Lake Michigan environmental survey. Final report. Great Lakes Research Division Special Report No. 49, University of Michigan. 67 pp.

Ayers, J.C., D.C. Chandler, G.H. Lauff, C.F. Powers and E.B. Henson. 1958. Currents and water masses of Lake Michigan. University of Michigan, Great Lakes Research Division Publication 3. 169 pp.

Bailey-Watts, A.E. 1976. Planktonic diatoms and silica in Loch Leven, Kinross, Scotland: a one month silica budget. Freshwater Biology 6:203-213. 
Beeton, A.M. and J.W. Moffett. 1964. Lake Michigan chemical data, 1954-55, 196061. U.S. Fish and Wildlife Service, Data Rept. 6 (U.S. Dept. Interior). 102 pp.

Cahill, R.A. 1981. Geochemistry of recent Lake Michigan sediments. Illinois State Geological Survey, Champaign. Circular 517.94 pp.

Calvert, S.E. 1983. Sedimentary geochemistry of silicon. In: S.R. Aston (ed.), Geochemistry and biogeochemistry, pp. 143-186. Academic Press, London.

Conway, H.L., J.I. Parker, E.M. Yaguchi and D.L. Mellinger. 1977. Biological utilization and regeneration of silicon in Lake Michigan. Journal of the Fisheries Research Board of Canada 34:537-544.

D'Elia, C.F., D.M. Nelson and W.R. Boynton. 1983. Chesapeake Bay nutrient and plankton dynamics: III. The annual cycle of dissolved silicon. Geochimica et Cosmochimica Acta 47:1945-1955.

DeMaster, D.J. 1981. The supply and accumulation of silica in the marine environment. Geochimica et Cosmochimica Acta 45:1715-1732.

Dobson, H.F.M., M. Gilbertson and P.G. Sly. 1974. A summary and comparison of nutrients and related water quality in Lakes Erie, Huron and Superior. Journal of the Fisheries Research Board of Canada 31:731-738.

Eisenreich, S.J., P.J. Emmling and A.M. Beeton. 1977. Atmospheric loading of phosphorus and other chemicals to Lake Michigan. Journal of Great Lakes Research 3:291-304.

Fee, E.J. 1973. A numerical model for determining internal primary production and its application to Lake Michigan. Journal of the Fisheries Research Board of Canada 30:1447-1468.

Glass, G.E. and J.E. Poldoski. 1975. Interstitial water components and exchange across the sediment interface of western Lake Superior. Verhandlungen der internationale Vereinigung für theoretische und angewandte Limnologie 19:405-420.

Glover, R.M. 1982. Diatom fragmentation in Grand Traverse Bay, Lake Michigan and its implications for silica cycling. Ph.D. thesis, University of Michigan. $204 \mathrm{pp}$.

Hecky, R.E., H.J. Kling, G.J. Brunskill and E.F. Fee. (in prep.). Seasonality of phytoplankton in large, shallow Canadian lakes and the significance of convective circulation of interstitial waters.

Hovey, N.W. 1968. Trace metal concentration and analysis of natural waters. University of Michigan, Great Lakes Research Division Special Report No. 41.48 pp.

Hutchinson, G.E. 1957. A treatise on limnology. Vol. I. Geography, physics, and chemistry. John Wiley \& Sons, New York. 1015 pp.

International Joint Commission. 1976. The waters of Lake Huron and Lake Superior. Vol. I. Summary and recommendations. Report to IJC by Upper Lakes Reference Group, Windsor, Ontario. $236 \mathrm{pp}$.

International Joint Commission. 1977. The waters of Lake Huron and Lake Superior. Vol. III (Part B). Lake Superior. Report to the IJC by Upper Great Lakes Reference Group. Windsor, Ontario. pp. 245-575.

Johnson, T.C. and S.J. Eisenreich. 1979. Silica in Lake Superior: mass balance considerations and a model for dynamic response to eutrophication. Geochimica et Cosmochimica Acta 43:77-91.

Ladewski, T.B. and E.F. Stoermer. 1973. Water transparency in southern Lake Michigan in 1971 and 1972. In: Proceedings 16th Conference Great Lakes Research. International Association of Great Lakes Research.pp. 791-807.

Nriagu, J.O. 1978. Dissolved silica in pore waters of Lakes Ontario, Erie, and Superior sediments. Limnology and Oceanography 23:53-67.

Officer, C.B. and J.H. Ryther. 1980. The possible importance of silicon in marine eutrophication. Marine Ecology Progress Series 3:83-91.

Parker, J.I. and D.N. Edgington. 1976. Concentration of diatom frustules in Lake Michigan sediment cores. Limnology and Oceanography 21:887-893.

Parker, J.I., H.L. Conway and E.M. Yaguchi. 1977. Dissolution of diatom frustules and recycling of amorphous silicon in Lake Michigan. Journal of the Fisheries Research Board of Canada 34:545-551.

Quigley, M.A. and J.A. Robbins. 1984. Silica regeneration processes in nearshore southern Lake Michigan. Journal of Great Lakes Research 10:383-392. 
Risley, C., Jr. and F.D. Fuller. 1965. Chemical characteristics of Lake Michigan, pp. 168-174. In: Proceedings 8th Conference Great Lakes Research, University of Michigan, Great Lakes Research Division Publication No. 13.

Robbins, J.A. 1980. Sediments of southern Lake Huron: elemental composition and accumulation rates. U.S. Environmental Protection Agency, Duluth, MN. EPA Rept. No. EPA-600/3-80-080. 310 pp.

Rousar, D.C. 1973. Seasonal and spatial changes in primary production and nutrients in Lake Michigan. Water, Air and Soil Pollution 2:497-514.

Saylor, J.H. and P.W. Sloss. 1976. Water volume transport and oscillatory current flow through the Straits of Mackinac. Journal of Physical Oceanography 6:229-237.

Schelske, C.L. 1975. Silica and nitrate depletion as related to rate of eutrophication in Lakes Michigan, Huron, and Superior. In: A.D. Hasler (ed.), Coupling of land and water systems. pp. 277-298. Springer-Verlag New York Inc., New York.

Schelske, C.L. (in prep.) Historical trends in Lake Michigan silica concentrations.

Schelske, C.L. and E. Callender. 1970. Survey of phytoplankton productivity and nutrients in Lake Michigan and Lake Superior. In: Proceedings 13 th Conference Great Lakes Research, International Association of Great Lakes Research. pp. 93105.

Schelske, C.L. and D.J. Conley. (in prep.). Historical changes in biogenic silica accumulation in Lake Michigan sediments.

Schelske, C.L. and J.C. Roth. 1973. Limnological survey of Lakes Michigan, Superior, Huron, and Erie. University of Michigan. Great Lakes Research Division Publication No. $17.108 \mathrm{pp}$.

Schelske, C.L. and E.F. Stoermer. 1971. Eutrophication, silica depletion, and predicted changes in algal quality in Lake Michigan. Science 173:423-424.

Schelske, C.L. and E.F. Stoermer. 1972. Phosphorus, silica, and eutrophication of Lake Michigan. In: G.E. Likens (ed.), Nutrients and eutrophication, Special Symposia Vol. 1, American Society of Limnology and Oceanography. pp. 157-171. Allen Press, Lawrence, Kansas.

Schelske, C.L., E.F. Stoermer, J.E. Gannon and M.S. Simmons. 1976. Biological, chemical and physical relationships in the Straits of Mackinac. U.S. Environmental Protection Agency, Ecological Research Series EPA 600/3-76-095. Environmental Research Laboratory, Duluth, Minnesota.

Schelske, C.L., L.E. Feldt and M.S. Simmons. 1980. Phytoplankton and physicalchemical conditions in selected rivers and the coastal zone of Lake Michigan, 1972. University of Michigan, Great Lakes Research Division Publication No. 19.162 pp.

Schelske, C.L., R.A. Moll and T.D. Berry. 1983a. Limnological characteristics of northern Lake Michigan. Part 1. Physical and chemical conditions. University of Michigan, Great Lakes Research Division, Special Report No. 95. 245 pp.

Schelske, C.L., E.F. Stoermer, D.J. Conley, J.A. Robbins and R.M. Glover. 1983b. Early eutrophication in the lower Great Lakes: new evidence from biogenic silica in sediments. Science 222:320-322.

Schelske, C.L., B.J. Eadie and G.L. Krausse. 1984. Measured and predicted fluxes of biogenic silica in Lake Michigan. Limnology and Oceanography 29:99-110.

Shapiro, J. and E.B. Swain. 1983. Lessons from the silica 'decline' in Lake Michigan. Science 221:457-459.

Sicko-Goad, L.M., C.L. Schelske and E.F. Stoermer. 1984. Estimation of carbon and silica content of diatoms from natural assemblages using morphometric techniques. Limnology and Oceanography 29:1170-1178.

Stoermer, E.F. 1978. Phytoplankton assemblages as indicators of water quality in the Laurentian Great Lakes. Transactions of American Microscopical Society 97:2-16.

Stoermer, E.F., J.P. Kociolek, C.L. Schelske and D.J. Conley. (in prep.) Diatom population succession in Lake Superior sediments.

Thomas, R.L. and C. Dell. 1978. Sediments of Lake Superior. Journal of Great Lakes Research 4:264-275.

Upchurch, S.B. 1972. Natural weathering and chemical loads in the Great Lakes. In: Proceedings 15th Conference Great Lakes Research, International Association of Great Lakes Research. pp. 401-415. 
Vollenweider, R.A., M. Munawar and P. Stadelmann. 1974. A comparative review of phytoplankton and primary production in the Laurentian Great Lakes. Journal of the Fisheries Research Board of Canada 31:739-762.

Weiler, R.R. 1978. Chemistry of Lake Superior. Journal of Great Lakes Research 4: $370-385$.

Weiler, R.R. 1981. Chemistry of the North American Great Lakes. Verhandlungen der internationale Vereinigung fur theoretische und angewandte Limnologie 21:16811694. 